\title{
Correction: Dowling, R., et al. Spatial Associations between Contaminated Land and Socio Demographics in Ghana. Int. J. Environ. Res. Public Health 2015, 12, 13587-13601
}

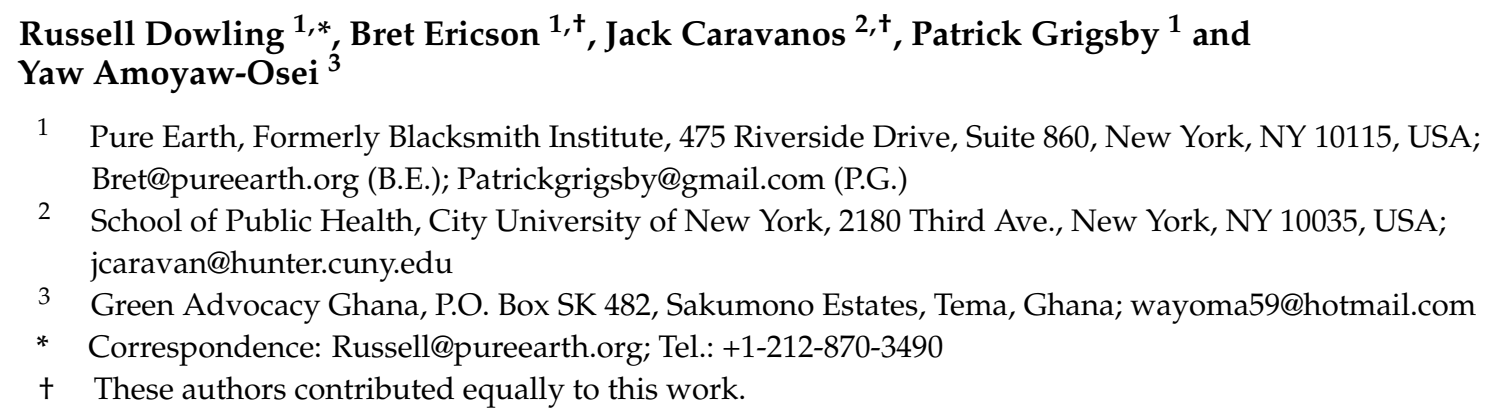

Academic Editors: Oladele A. Ogunseitan and Paul B. Tchounwou

Received: 17 February 2016; Accepted: 17 February 2016; Published: 24 February 2016

The author wishes to make the following correction to this paper [1]. Due to mislabeling, we replaced the original caption of Figure 1:

Figure 1. Regional map of Ghana. Source: MAGELLAN Geographics, 1992 [15]. with:

Figure 1. Regional map of Ghana. Source: Ezilon, 2009 [15].

The updated reference [2] for this figure is as follows:

15. Ghana Map_Political Map of Ghana. Available online: http://www.ezilon.com/maps/ africa/ghana-maps.html (accessed on 12 February 2016).

The authors would like to apologize for any inconvenience caused to the readers by these changes.

Conflicts of Interest: The authors declare no conflicts of interest.

\section{References}

1. Dowling, R.; Ericson, B.; Caravanos, J.; Grigsby, P.; Amoyaw-Osei, Y. Spatial associations between contaminated land and socio demographics in Ghana. Int. J. Environ. Res. Public Health 2015, 12, 13587-13601. [CrossRef] [PubMed]

2. Ghana Map_Political Map of Ghana. Available online: http://www.ezilon.com/maps/africa/ghana-maps.html (accessed on 12 February 2016).

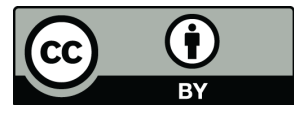

(c) 2016 by the authors; licensee MDPI, Basel, Switzerland. This article is an open access article distributed under the terms and conditions of the Creative Commons by Attribution (CC-BY) license (http://creativecommons.org/licenses/by/4.0/). 